\title{
CURAHANAN TENAGA KERJA DAN PENDAPATAN USAHATANI UBIKAYU (Manihot esculenta Crantz) TERHADAP PENDAPATAN RUMAH TANGGA PETANI (Studi di Desa Purabaya Kecamatan Purabaya Sukabumi Jawa Barat)
}

\author{
Dede Suryana ${ }^{1}$ Himmatul Miftah $^{1 \mathrm{a}}$, Yodfiatfinda $^{1}$ \\ ${ }^{1}$ Jurusan Agribisnis, Fakultas Pertanian Universitas Djuanda Bogor, \\ Jl Tol Ciawi No. 1 PO Box 35 Ciawi Bogor 16720, \\ ${ }^{a}$ Korespondensi: Himmatul Miftah, Telepon: 0251-8240773, E-mail: hmiftah@yahoo.co.id;
}

\begin{abstract}
Cassava growing demand not accompanied by an increase in income of farmers. To cover the household expenses of farmers working in the field of non-farm activities. The study aims to analyze the level of household income and cassava farming contribution to total household income of farmers. The study was conducted in the village of the District Purabaya Purabaya Sukabumi, conducted in April until the month of June 2013. The location selected purposively as Simple Random Sampling sample of 36 farmers. In conclusion average household income peani Rp. 5,721,639 per year, or Rp. 476800 per month. Operating revenues, contributing 59 percent of cassava, of non cassava farming by 9 percent and beyond farm trade and services that amounted to 32 percent of total household income of Rp 40,553,344, -
\end{abstract}

Key words : Cassava, Farm's revenue, Labour.

\begin{abstract}
ABSTRAK
Permintaan ubikayu yang meningkat tidak diikuti dengan peningkatan pendapatan petaninya. Untuk menutupi pengeluaran rumahtangganya petani bekerja di bidang kegiatan non pertanian. Penelitian bertujuan menganalisis tingkat pendapatan rumah tangga dan kontribusi usahatani ubikayu terhadap total pendapatan rumah tangga petani. Penelitian dilakukan di Desa Purabaya Kecamatan Purabaya kabupaten Sukabumi, dilaksanakan bulan April sampai dengan Bulan Juni 2013. Lokasi dipilih secara purposive secara Simpel Random Sampling jumlah sampel 36 petani. Kesimpulannya Rata-rata pendapatan rumah tangga peani sebesar Rp. 5.721.639 per tahun atau sebesar Rp. 476.800 per bulan. Kontibusi Pendapatan usaha ubikayu sebesar 59 persen, dari usahatani non ubikayu sebesar 9 persen dan di luar usahatani yaitu dagang dan jasa sebesar 32 persen dari total pendapatan rumah tangga Rp 40.553.344,-

Kata kunci : Ubi kayu, Pendapatan usahatani, Tenaga kerja
\end{abstract}





\section{PENDAHULUAN}

Kabupaten Sukabumi merupakan salah satu sentra produksi Ubikayu di provinsi Jawa barat, dengan produksi Ubikayu pada tahun 2010 sebesar 155.775 ton, dan luas panen 7.919 Ha. Hal ini mengalami peningkatan jika dibandingkan dengan tahun sebelumnya yaitu produksi sekitar 139.545 ton dan luas panen sekitar 7.132 ha (BPS tahun 2011). Salah satu Sentra Produksi ubikayu adalah Kecamatan Purabaya khususnya Desa Purabaya.

Permintaan dari Ubikayu yang tinggi pada satu sisi, namun di sisi lain untuk memenuhi permintaan tersebut, dijumpai kendala antara lain rendahnya penerapan teknologi, terbatasnya modal usahatani, sempitnya lahan skala usaha, curahan tenaga kerja yang terkadang tidak seimbang dengan besarnya usahatani yang dijalankan, menyebabkan produktivitas usahatnai ubikayu rendah, sehingga akan mengurangi pendapatannya. Alokasi curahan tenaga kerja pada usahatani ubikayu yang dijalankan oleh petani terkadang hanya berdasar atas pengalaman saja, sehingga jumlah luas lahan yang digarap tidak sebanding dengan curahan tenaga kerja yang seharusnya atau sebaliknya sehingga berpengaruh terhadap produktivitas dan banyaknya sisa waktu yang terbuang. Berdasarkan latar belakang di atas maka penelitian ini berusaha untuk melihat peranan usahatani ubikayu terhadap pendapatan rumah tangga petani dan melihat berapa curahan tenaga kerja yang digunakan atau dialokasikan oleh petani pada usahatani ubikayu yang dilakukannya sehingga memberikan kontribusi yang cukup singnifikan terhadap pendapatan rumah tangga petani tersebut. Tujuan Penelitian adalah menganalisis tingkat pendapatan rumah tangga dan kontribusi usahatani ubikayu terhadap total pendapatan rumah tangga petani.

\section{METODE PENELITIAN}

Penelitian dilaksanakan bulan April sampai dengan Bulan Juni 2013 di Desa Purabaya Kecamatan Purabaya Kabupaten Sukabumi Provinsi Jawa Barat. Lokasi dipilih secara purposive. Pengambilan sampel petani secara Simpel Random Sampling, jumlah sampel dilakukan dengan metode slovin dengan menentukan taraf keyakinan $85 \%$. Jumlah petani 183 sehingga diperoleh sampel 36 petani. Pengumpulan data dilakukan melalui observasi langsung dan wawancara. Analisis data dilakukan secara deskriptif dan kuantitatif.

\section{HASIL DAN PEMBAHASAN}

\section{Karakteristik Petani Responden}

\section{Umur Petani Responden}

Berdasarkan hasil penelitian, umur petani sampel kebanyakan berada pada rentang usia 41-60 tahun dengan persentase 55 persen. Tabel umur petani sampel dapat dilihat pada tabel 1 .

Tabel 1. Jumlah Petani Responden Berdasarkan Umur

\begin{tabular}{cccr}
\hline No & $\begin{array}{c}\text { Umur Petani } \\
\text { Responden (Tahun) }\end{array}$ & $\begin{array}{c}\text { Jumlah Petani } \\
\text { (Orang) }\end{array}$ & Persentase (\%) \\
\hline 1 & $0-20$ & 0 & 0 \\
2 & $21-40$ & 6 & 16.67 \\
3 & $41-60$ & 20 & 55.5 \\
4 & $61-80$ & 9 & 25 \\
5 & $81-100$ & 1 & 2.7 \\
& Jumlah & 36 & 100 \\
\hline
\end{tabular}

Sumber : Data Primer (2013), diolah 



\section{Penguasan Lahan}

Pada umumnya berdasarkan penguasan dan kepemilikan lahan, petani respoden di Desa Purabaya, tergolong petani dengan kepemilikan lahan yang relatif sempit. Keragaan petani responden berdasarkan penguasaan lahan dapat dilihat pada tabel 2 .

Tabel 2. Jumlah Petani Responden Berdasarkan Penguasaan Lahan

\begin{tabular}{cccc}
\hline No & Luas Lahan $(\mathrm{Ha})$ & Jumlah Petani(Orang) & Persentase $(\%)$ \\
\hline 1 & $\leq 1$ & 26 & 72.2 \\
2 & $1-2$ & 4 & 11.1 \\
3 & $\geq 2$ & 6 & 16.7 \\
& Jumlah & 36 & 36.0 \\
\hline
\end{tabular}

Sumber : Data Primer (2013), diolah

\section{Pengalaman Usahatani}

Jumlah petani responden berdasarkan pengalaman usahatani dapat dilihat pada tabel 3. Berdasarkan hasil penelitian bahwa sebagian besar petani sudah memiliki pengalaman yang cukup yaitu berkisar antara 10-30 tahun yaitu sebanyak 25 orang petani.

Tabel 3. Jumlah Petani Responden Berdasarkan Kriteria Pengalaman Usahatani

\begin{tabular}{cccc}
\hline No & $\begin{array}{c}\text { Pengalaman Usahatani } \\
\text { (Tahun) }\end{array}$ & JumlahPetani(Orang) & Persentase (\%) \\
\hline 1 & $\leq 10$ & 4 & 11.2 \\
2 & $10-30$ & 25 & 69.4 \\
3 & $\geq 30$ & 7 & 19.4 \\
& Jumlah & 36 & \\
\hline
\end{tabular}

Sumber : Data Primer (2013), diolah

\section{Keragaan Usahatani Ubikayu}

Keragaan usatahani ubikayu petani responden berdasarkan status lahan yang dimilikanya dapat dilihat pada tabel 4 .
Berdasarkan hasil penelitian sebanyak 29 petani merupakan petani penggarap dan hanya terdapat 4 orang petani yang memiliki lahan sendiri. Ha

Tabel 4. Keragaan petani responden berdasarkan status kepemilikan lahan

\begin{tabular}{clcr}
\hline No & Satatus Lahan & Jumlah (orang) & Persentase (\%) \\
\hline 1 & Milik Sendiri & 4 & 11.1111 \\
2 & Garap & 29 & 80.5555 \\
3 & Sewa & 3 & 8.3333 \\
& & 36 & 100 \\
\hline
\end{tabular}

Sumber : Data Primer (2013), diolah

\section{Tingkat Pendidikan}

Keragaan tingkat pendidikan petani sampel dapat dilihat pada tabel 5. Tingkat pendidikan petani di daerah penelitian tergolong rendah, yaitu sebanyak 33 orang atau 92 persen petani hanya memiliki tingkat pendidikan sekolah dasar dengan 3 orang petani memiliki tingkat pendidikan lebih baik yaitu sekolah menengah atas (SMP). 
Tabel 5. Jumlah Petani Responden Berdasarkan Tingkat Pendidikan

\begin{tabular}{cccc}
\hline No & Pendidikan (Tahun) & Jumlah Petani (Orang) & Persentase (\%) \\
\hline 1 & Tidak Tamat SD & 0 & 0 \\
2 & SD & 33 & 92 \\
3 & SMP & 3 & 8 \\
4 & SMA & 0 & 0 \\
5 & Perguruan Tinggi & 0 & 0 \\
& Jumlah & $\mathbf{3 6}$ & $\mathbf{1 0 0}$ \\
\hline
\end{tabular}

Sumber : Data Primer (2013), diolah

\section{Analisis Usahatani Ubikayu}

Perhitungan pendapatan dan rasio penerimaan usahatani ubikayu di Desa Purabaya dapat dilihat pada Tabel 6.
Perhitungan usahatani ini meliputi penerimaan, biaya tetap, biaya variabel, nilai $\mathrm{R} / \mathrm{C}$ rasio dan nilai $\mathrm{B} / \mathrm{C}$ rasio.

Tabel 6. Perhitungan Pendapatan dan Rasio Penerimaan Terhadap Biaya (R/C) Usahatani Ubikayu di Desa Purabaya Tahun 2012.

\begin{tabular}{|c|c|c|c|c|c|}
\hline Uraian & Satuan & Harga (Rp) & Jumlah fisik & Nilai (Rp) & $\%$ \\
\hline A. Penerimaan & $\mathrm{Kg}$ & 850 & 24.000 & 20.400 .000 & \\
\hline \multicolumn{6}{|l|}{ B. Biaya produksi } \\
\hline \multicolumn{6}{|l|}{ Biaya Tetap } \\
\hline \multicolumn{6}{|l|}{ 1. Tenaga Kerja } \\
\hline - Pengolahan lahan & HKP & 30.000 & 5 & 1.500 .000 & 12.048 \\
\hline - Penanaman & HKP & & 5 & 2.000 .000 & 16.064 \\
\hline & HKW & & 10 & & \\
\hline - Pemupukan & HKP & & 10 & 3.000 .000 & 24.096 \\
\hline - Penvian gan dan & $\begin{array}{l}\text { HKW } \\
\text { HKP }\end{array}$ & & $\begin{array}{l}20 \\
10\end{array}$ & & \\
\hline pembubunan & HKW & & 20 & 3.000 .000 & 24.096 \\
\hline Biaya Tetap Total & & & & 9.500 .000 & 76.305 \\
\hline Biaya Variabel & & & & & \\
\hline 1. Bibit & Stek & 150 & 8.000 & 1.200 .000 & 9.63 \\
\hline $\begin{array}{l}\text { 2. Pupuk Kandang } \\
\text { 3. Pupuk kimia }\end{array}$ & Karung & 10.500 & 100 & 1.050 .000 & 8.43 \\
\hline - Urea & $\mathrm{Kg}$ & 2.400 & 100 & 240.000 & 1.92 \\
\hline - TSP & $\mathrm{Kg}$ & 2.800 & 100 & 280.000 & 2.24 \\
\hline$-\mathrm{KCl}$ & $\mathrm{Kg}$ & 1800 & 50 & 90.000 & 0.72 \\
\hline Biaya Variabel Total & & & & 2.950 .000 & 23.6 \\
\hline C. Biaya Total $(C+D)$ & & & & 12.450 .000 & \\
\hline D. Keuntungan (A-E) & & & & 7.950 .000 & \\
\hline E. R/C $(\mathrm{A} / \mathrm{E})$ & & & & 1.64 & \\
\hline F. B/C (F/E) & & & & 0.64 & \\
\hline
\end{tabular}

Berdasarkan Tabel 6 Dapat kita ketahui bahwa biaya yang dikeluarkan oleh petani responden dalam kegiatan usahatani ubikayu terdiri dari baiaya tetap dan biaya varibel, yaitu biaya tenaga kerja (pengolahan lahan, penanaman, pemupukan, dan perawatan), biaya pembelian pupuk (kandang dan kimia), biaya sebesar Rp 12.450.000.Penerimaan yang didapat petani responden dari usahatani ubikayu sebesar Rp 20.400.000 yang berasal dari jumlah $24.000 \mathrm{~kg}$ 
ubikayu yang dijual dikalikan dengan harga per kg singkong pada saat penelitian berlangsung.

\section{Analisis $\mathbf{R} / \mathrm{C}$ ratio}

Berdasarkan, analisis R/C yang dilakukan nilai $\mathrm{R} / \mathrm{C}$ yang diperoleh dari usahatani yang dijalankan petani responden adalah 1.64 yang diperoleh dari total revenue/total biaya (Rp 20.400.000/Rp 12.450.000), jika dikaitkan dengan teori yang sudah ada nilai $\mathrm{R} / \mathrm{C}$ yang diperolehsebesar 1.64 menunjukan usahatani ubikayu yang dijalankan petani responden layak untuk diusakan dan dijalankan. Berdasarkan nilai ini menunjukan bahwa usahatani dengan pengeluaran Rp. 1.00 maka akan menghasilakan penerimaan Rp. 1.64.

\section{Analisi $\mathrm{B} / \mathrm{C}$ ratio}

Selanjutnya, berdasarkan Analaisis $\mathrm{B} / \mathrm{C}$, usahatani yang dijalankan petani responden ubikayu di desa purabaya bernilai 0.64 yang diperoleh dari keuntungan/total baiaya (Rp.7.950.000/12.450.000 = 0.64). artinya, setiap Rp. 1,00 yang dikeluarkan oleh petani responden untuk usahatani yang dijalankan akan mendapatkan 0.64. Atau dengan kata lain besarnya keuntungan adalah $64 \%$ dari seluruh biaya yang dikeluarkan petani responden.

Berdasarkan Tabel di atas, penerimaan usahatani ubikayu petani responden yang dihitung atas penerimaan jumlah kli gram ubikayu dalam satu hektar lahan dikalikan dengan harga pada saat penetian berlansung. Rata-ta jumlah produksi ubikayu yang dilakukan petani responden adalah $24.000 \mathrm{~kg}$ per hektar dengan asumsi perhektas $7.500-8.000$ pohon maka hasil rata-rata per pohon ubikayu yang ditanam petani responden adalah 3.0 - $3.2 \mathrm{~kg}$ dengan harga jual pada saat itu adalah Rp. 830 - 850 per kg, terima di kebun. Penerimaan rata-rata yang diperoleh petani responden adalah sebesar Rp. 24.400.000.
Biaya usahatani ubikayu terdiri dari biaya tetap dan biaya variabel. Biaya tetap yang dikeluarkan oleh petani responden meliputi biaya pengolahan lahan, penanaman, pemupukan dan perawatan. Biaya variabel merupakan biaya yang dikeluarkan petani untuk mendukung kegiatan produksi ubikayu. Biaya variabel meliputi biaya pembelian bibit, pupuk (kandang dan kimia). Biaya produksi terbesar yang dikeluarkan oleh petani responden dalam menjalankan usahatani ubikayu adalah pada saat pemupukan dan perawatan sebesar Rp. 3.000.000 atau 24.096 persen dari biaya total.

Komponen biaya produksi terbesar ke dua adalah biaya untuk tenaga kerja untuk penanaman yaitu sebesar 16.064 persen dari total biaya yang dikeluarkan atau sebesar Rp. 2.000.000. Sedangkan komponen biaya terbesar ke tiga adalah biaya pengolahan lahan yaitu sebesar $\mathrm{Rp}$. 1.500.000 atau sama dengan 12..048 persen. Komponan lainya yaitu biaya varibel yang terdiri dari pembelian pupuk (kandang dan kimia (Urea, Tsp dan Poska)), pembelian bibit hanya menghabiskan sebanyak 23. 06 persen dari seluruh total biaya atau sebesar Rp. 2.950.000.

Pendapatan usahatani merupakan selisih antara penerimaan usahatani dengan pengeluaran usahatani. Komponen pendapatan usahatani terdiri atas pendapatan atas biaya tunai dan pendapatan atas biaya total. Analisis R/C rasio digunakan untuk menunjukan perbandingan antara nilai output terhadap nilai inputnya sehingga dapat diketahui kelayakan usahatani yang diusahakan petani responden ubikayu yang ada di tempat penelitian.

Pada usahatani ubikayu petani responden di desa purabaya satu hektar ubikayu yang diusahakan rata-rata menghasilakan produksi $24.000 \mathrm{~kg}$ dengan harga rata-rata pada tingkat petani berkisar antara Rp. 850 - 1000 / kg, sehingga ratarata total penerimaan yang di peroleh 
petani responden sebesar Rp 20. 400.000/ ha. Jika rata-rata total pengeluaran (total biaya) per hektar sebesar Rp 12.400.000 maka pendapatan atas biaya total adalah sebesar Rp 7.950.000 / ha.

\section{Pendapatan Rumahtangga}

\section{Pendapatan}

Pendapatan rumahtangga berasal dari penghasilan rumahtangga petani berasal dari berbagai sumber, yaitu dari kegiatan usahatani, luar usahatani dan dari sumber lainnya. Pendapatan rumahtangga petani dari sektor pertanian diperoleh dari usaha ubikayu, padi, palawija, tanaman hortikultura, dan hasil dari hutan. Pendapatan usaha luar sektor pertanian adalah dari berdangang, jasa (bangunan, buruh tani, guru). Dilihat dari pendapatan rumahtangga petani responden di desa purabaya dan sumbernya, maka sebagian besar rumahtangga petani memperoleh pendapatan dari usahatani dan buruh tani.

Pendapatan yang bersumber dari usaha on farm (sektor pertanian) sebagian besar berasal dari usahatani ubi kayu, padi, tanaman hortikultura dan palawija.Periode waktu penerimaan pendapatan yang cukup panjang dari usahatani ubi kayu disebabkan karena panjangnya waktu satu periode masa tanam ubikayu yang mencapai satu tahun. Oleh karena itu petani biasanya menanam tanaman lain yang periode nya lebih sebentar dan bisa ditanam di lahan yang sama, seperti padi, jagung, mentimun dan kacangkacangan.Sedangakan Pendapatan dari sektor off farmdiantaranya adalah kegiatan buruh tani yang dilakukan mulai dari pengolahan tanah sampai dengan penen pada kegiatan usahatani padi sawah di lahan milik orang lain. Pendapatan yang diterima berasal dari jasa pengolahan tanah, tanam, perawatandan jasa sebagai tenaga kerja panen.Selanjutanya pendapatan tersebut merupakan asumsi hitungan dengan periode akumulasi per tahun pendapatan dari seluruh sumber pendapatan di atas. Hal tersebut dikarenakan tidak adanya pencatatan yang rutin setiap bulan yang dilakukan petani responden terhadap pendapatan rumahtangganya.

Sumber pendapatan petani dibidang non farm bersumber dari tukang, buruh bangunan dan berdagang. Berbeda dengan kegiatan pada on farm dan off farm, kegiatan non farm aktivitasnya sangat kecil sekali dipengaruhi oleh musim yang bersifat aksidental, misalkan momen lebaran dan hari-hari penting dan bersejarah. Dan kegiatan tersebut dilakukan biasanya setelah masa tanam dan perawatan selesai. Sehingga ketika menunggu panen rumahtangga tetap memperolah pendapatan.

Masyarakat desa purabaya berdasarkan luas penguasaan lahan yang dimiliki dapat dikelompokkan menjadi petani yang memiliki lahan garapan/pribadi yang relatif luas dan yang memiliki lahan garapan/pribadi yang sempit atau kurang dari 0,25 ha. Pengaruh perbedaan luas pemilikan lahan berdampak pada jenis usaha yang dikerjakan untuk memperoleh pendapatan dan besarnya pendapatan yang diterima dari masing-masing sumber.

$$
\text { Petani dengan lahan }
$$

garapan/pribadi yang luas menjadikan usaha on farm khususnya tanaman ubikayu, dan padi sebagai usaha utama dan menjadi salah satu sumber penerimaan pendapatan yang terbesar, menyusul usaha off farm dan non farm. Pendapatan yang bersumber dari kegiatan off farm dan non farm menempati peringkat yang lebih rendah dibandingkan dengan yang dari kegiatan on farm. Salah satu kegiatan off farm, yaitu bekerja menjadi buruh tani sebagai tenaga kerja upahan, kurang mendapat perhatian dari petani yang memiliki lahan garapan luas. Disamping karena waktunya lebih banyak tersita untuk kegiatan on farm.

Sebaliknya terjadi pada petani dengan luas lahan garapan/pribadi yang sempit, usaha dari kegiatan off farm memegang peranan penting sebagai sumber pendapatan. Bekerja menjadi 
buruh tani sebagai tenaga kerja upahan merupakan sumber pendapatan terbesar untuk menunjang kehidupan keluarga. Sumber pendapatan selanjutnya yang menjadi andalan keluarga petani dengan lahan garapan/pribadi yang sempit yaitu dari kegiatan non farm. Penguasaan faktor produksi petanian seperti tanah, tenaga kerja dan modal yang relatif rendah oleh petani dengan luas lahan garapan/pribadi yang sempit mendorong mereka melakukan tindakan penyelamatan diri dengan mencari sumber pendapatan lain. Uraian tersebut memberikan gambaran bahwa sumber pendapatan rumah tangga di Desa Sambelia tertinggi berasal dari kegiatan on farm. Tanpa mengelompokkan petani kaya dan petani miskin.

\section{Pendapatan On Farm}

Dari sektor On Farm, sumber pendapatan petani berasal dari hasil panen ubikayu, padi, jagung dan kacang tanah. Pendapatan yang bersumber dari hasil panen ubikayu biasanya diperoleh dalam jangka waktu satu tahun atau sekurangkurangnya sepuluh bulan dari masa tanam. Hal ini disebabkan jangka waktu produksi ubikayu yang mencapai satu tahun. Sedangkan pendapatan yang bersumber dari hasil panen padi, jagung dan kacang tanah diterima petani tiga bulan dari masa tanama ubikayu, hal tersebut dikarenakan lahan yang digunakan untuk menanam ketiga jenis tanaman tersebut menggunakan sistem tumpang sari di areal lahan ubikayu. Pendapatan yang diperoleh petani dari usahatani padi, jagung, dan kacang tanah, biasanya tidak secara bersamaan, karena pada umumnya di areal tanaman ubikayu, petani hanya menanam satu jenis tanaman sela.

\section{Pendapatan Off Farm}

\section{Buruh Tani}

Kegiatan buruh tani yang dilakukan oleh masyaraktat Desa Purabaya biasanya dilakukan setelah masa tanam ubikayu selesai. Kegiatan buruh tani ini ada yang bersifat sosial ada juga yang komersial. Kegiatan buruh tani yang sosial biasanya dilakukan ketika penanaman singkong, hal tersebut dikarenakan petani lainnya membantu ketika petani tersebut sedang menanam ubikayu di lahan garapannya. Kegiatan buruh tani itu meliputi; pengolahan tanah, perawatan, pemupukan, bahkan sampai peroses panen.

Selain itu kegiatan buruh tani juga dilakukan masyarakat untuk tanaman lain, seperti padi, jagung, dan kacang tanah. Kegiatan buruh tani untuk ketiga jenis di atas meliputi; mencangkul, tandur (tanam Padi), ngarambet/ngoyos (pembersihan gulama) dan dibuat (panen).

\section{Dagang}

Kegiatan berdagang yang dilakukan oleh petani responden di Desa Purabaya terdiri dari beberapa jenis perdagangan berupa sembako, pakean, dan warung-warung kecil. Alokasi waktu yang diluangkan oleh petani responden untuk melakukan kegiatan perdagangan dimulai setelah shalat dzuhur sampai menjelang maghrib. Hal ini dikarenakan dari pagi sampai jam dua belas siang petani mengurus lahan pertaniannya sendiri. Namun demikian sebagian rumah tangga petani responden ada yang berjualan dari pagi sampai sore, kegiatan berdagangannya dilakukan oleh istrinya dengan membuka warung-warung kecil. Jenis usaha yang dijalankan cendrung bervariatif, mulai dari penjual motor sampai penjual perlengkapan rumah tangga dan baju-baju dengan sistem kredit.

\section{Kontribusi Jenis Usaha Terhadap Pendapatan Rumah Tangga}

Masyarakat desa Purabaya berdasarkan luas penguasaan lahan yang dimiliki dapat dikelompokan kepada petani yang memiliki lahan garapan luas dan yang memiliki lahan garapan sempit atau kurang dari 0,25 ha. Petani dengan lahan garapan yang luas menjadikan usaha on farm khususnya tanaman pangan, sebagai usaha utama dan menjadi salah satu sumber penerimaan pendapatan 
keluarga yang terbesar, menyusul usaha off farm dan non farm. Pendapatan yang bersumber dari kegiatan non farm menempati peringkat yang lebih rendah dibandingkan dengan kegiatan on farm. Salah satu kegiatan off farm, yaitu bekerja menjadi buruh tani sebagai tenaga kerja upahan, sedikit dilakukan oleh petani yang memiliki lahan garapan luas.

Sebaliknya terjadi pada petani dengan luas lahan garapan sempit atau petani miskin, usaha dari kegiatan off farm memegang peranan penting sebagai sumber pendapatan keluarga. Bekerja menjadi buruh tani sebagai tenaga kerja upahan merupakan sumber pendapatan terbesar untuk menunjang kehidupan keluarga. Penguasaan faktor produksi petanian seperti tanah, tenaga kerja dan modal yang relatif rendah oleh petani dengan luas lahan garapan sempit mendorong mereka melakukan tindakan penyelamatan diri dengan mencari sumber pendapatan lain. Usaha tanaman pangan oleh petani dengan lahan garapan sempit (petani miskin) lebih banyak bersifat subsisten.

\section{Kontribusi Usahatani Ubikayu Terhadap Pendapatan Rumah Tangga Petani}

Pada sebagian besar petani responden di desa Purabaya, ubikayu merupakan tanaman yang diunggulkan, hal tersebut dikarenakan sebagian besar petani memiliki lahan ubikayu. Tidak hanya itu menurut hasil wanwancara dari apartur desa bahwa ubikayu merupakan tanaman perimadona desa tersebut. Penerimaan petani yang berasal dari usahatani ubikayu merupakan pendapatan yang digunakan untuk memenuhi kebutuhan petani responden sehari-hari disamping pendapatan yang berasal dari usahatani luar ubikayu dan usaha luar usahatani.

Rata-rata kontribusi masing-masing usaha yang dilakukan petani responden di desa Purabaya bervariatif, hal ini dikarenakan jumlah penguasaan lahan dan tingkat pendidikan cara yang berbedabeda. Berikut adalah bagan rata-rata kontribusi masing-masing pendapatan usaha terhadap pendapatan rumahtangga petani di desa Purabaya disajikan pada Tabel 7.

Tabel 7. Bagan Kontribusi Masing-Masing Usaha Terhadap Pendapatan Rumahtangga Petani

\begin{tabular}{crccc}
\hline No & \multicolumn{2}{c}{ Jenis Usaha } & Jumlah Pendapatan (Rp/Tahun) & Persentase (\%) \\
\hline \multirow{2}{*}{1} & \multirow{2}{*}{ Usahatani } & Ubikayu & 20.671 .361 & 59 \\
& & Luar Ubikayu & 2.947 .500 & 9 \\
2 & Luar Usahatani & 16.934 .483 & 32 \\
& Jumlah & 40.553 .344 & 100 \\
\hline
\end{tabular}

Sumber : Data primer diolah

Dari tabel di atas dapat dilihat bahwa, jenis usaha yang berkontribusi paling besar terhadap pendapatan rumah tangga petani adalah usahatani ubikayu Rp. 20.671.361 atau $59 \%$ dari total pendapatan, kemudian diikuti adalah luar usahatani sebesar Rp. 16.934.483 atau 32 $\%$ dari total pendapatan, dan kontribusi jenis usaha yang ketiga adalah usahatani luar ubikayu sebesar $9 \%$ dari total pendapatan petani responden di desa. Hal tersebut menunjukan bahwa usahatani ubikayu merupakan mata pencaharian utama dalam usaha pemenuhan kebutuhan rumah tangga petani.

\section{KESIMPULAN DAN IMPLIKASI KEBIJAKAN}

\section{Kesimpulan}

Berdasarkan hasil penelitian dapat disempulkan bahwa rata-rata pendapatan rumah tangga petani ubi kayu di desa Purabaya adalah sebesar Rp. 5.721.639 per tahun atau sebesar Rp. 476.800 per bulan. Kontibusi usaha di luar usahatani, yaitu usahatani luar ubikayu dan usaha diluar 
usahatani masing masing menempati urutan kedua dan ketiga. Usaha diluar usahatani yang terdiri dari usaha perdagangan dan jasa menempati urutan kedua terbesar setelah usahatani ubikayu, yaitu sebesar Rp. 16.934.483 atau $32 \%$ dari total pendapatan, sedangkan usahatani luar ubikayu menempati urutan ketiga yaitu sebesar Rp. 2.947.500 atau $9 \%$ dari total penerimaan.

\section{Implikasi Kebijakan}

Meningkatkan curahan tenaga kerja dan luas lahan untuk usahatani ubikayu, sehingga pendapatan rumah tangga petani akan meningkat seiring dengan perbaikan kualitas produk dan perluasan areal lahan yang dapat meningkatkan produksi. Petani disarankan menambah curahan jam kerja pada usaha luar usahatani (dagang dan jasa).

\section{DAFTAR PUSTAKA}

Badan Pusat Statistika. 2010. Jawa Barat dalam Angka. Bandung

Badan Pusat Statistika. 2011. Kabupaten Sukabumi dalam Angka. Bandung Hernanto, F. 1995. Ilmu usahatani. Penebar swadaya. Jakarta.

Soekarwati. 1995. AnalisisUsaha Tani. Jakarta: UI Press.

Soekartawi.1996. Ilmu Usahatani. Rajawali Press, Jakarta 